\title{
Autofagia eta haren erregulazioa osasunean eta gaixotasunean
}

\section{(Autophagy and its regulation in health and disease)}

\author{
Iñaki Milton-Laskibar*, Leixuri Aguirre, María Puy Portillo \\ Farmazia eta Elikagaien Zientziak Saila. Farmazia Fakultatea, Arabako Campusa. \\ Euskal Herriko Unibertsitatea (UPV/EHU) \\ CIBERobn, Instituto de Salud Carlos III. 28029 Madril \\ *inaki.milton@ehu.eus
}

DOI: $10.1387 /$ ekaia.19621

Laburpena: Autofagia zelula eukariotikoetan berez gertatzen den prozesu bat da, zeinak oreka homeostatikoa mantentzea ahalbidetzen duen (kaltetutako egitura zelularrak degradatuz eta energia-oreka mantenduz) zelula estres edo energia eskuragarritasun mugatuko egoeretan dagoenean. Autofagiari buruz hitz egitean, apoptositik bereiztea komeni da. Oro har, autofagia babes-mekanismotzat hartzen da, zelulek estres maila ez-hilgarrietara egokitzeko ematen duten erantzuntzat. Zelulak pairatzen duen estresak muga jakin bat gainditzen duenean, edo estres maila bat denboran mantentzen denean, apoptosia aktibatuko da, zelula deuseztatzeko. Egundaino, hiru autofagia mota deskribatu dira: xaperoi bidezko autofagia, mikroautofagia eta makroautofagia. Hiru motek duten ezaugarri komuna da lisosoma bidez zitosoleko materialaren degradazioa gertatzen dela. Oro har, autofagiak zelularen funtzio egokia eta biziraupena bermatzen ditu, eta, ondorioz, horren asaldurak zelularen funtzionamendua kaskartzen du, zenbait gaixotasunen agerpenari bide eginez. Autofagiak (edo haren asaldurak) zenbait gaixotasun eta egoeraren (neuroendekapenezko gaixotasunak, diabetesa, obesitatea, gibel gantzatsu ez-alkoholikoa edo zahartzea) sorrera eta garapenarekin duen erlazioa dela eta, komunitate zientifikoa aspalditik dabil prozesu hau aktibatzen edo egoera normalera itzultzen duten molekula edo esku-hartzeen bila. Hala ere, gaur egun prozesu honen aktibazioak eragindako efektu guztiak oraindik ezagutzen ez direnez, beharrezkoa da gizakiekin ikerketa gehiago egitea mekanismo hau helburu terapeutikoekin erabili ahal izateko.

Hitz gakoak: Autofagia, erregulazioa, osasuna, gaixotasuna.

Abstract: Autophagy, is a process that occurs constitutively in all eukaryotic cells that helps maintaining the correct homeostatic balance (degrading damaged cellular compo- 
nents and maintaining the energy balance) in situations of stress or limited energy availability. When referring to autophagy, it must be differentiated from apoptosis. In general, autophagy is a protective mechanism which allows the adaptation of the cell to non-lethal stress levels. When this stress reaches a certain level, or is maintained during time, apoptosis is activated in order to degrade the whole cell. To date, three types of autophagy have been described, which are chaperone-mediated autophagy, microautophagy and macroautophagy, being the lysosomal degradation of cytoplasmic material the common characteristic in all of them. In general, autophagy guarantees a correct cellular function and survival, and consequently, its impairment affects negatively the cellular performance, leading to the appearance of different diseases. Due to the relationship between autophagy and the onset and development of several disease and situations (neurodegenerative diseases, diabetes, obesity, non-alcoholic fatty liver disease or aging) scientific community has been interested on looking for molecules or interventions that activate or restore this process. Nevertheless, the lack of knowledge regarding secondary effects that may occur as a result of the activation of this process, more studies conducted in humans are needed before its use with therapeutic purposes.

Keywords: Autophagy, regulation, health, illness.

\section{SARRERA}

Autofagia, 'nork bere burua jatea' grezieraz, zelula eukariotikoetan berez gertatzen den prozesu bat da, zeinak oreka homeostatikoa mantentzea ahalbidetzen duen. Horretarako, kaltetuta dauden edota behar bezala funtzionatzen ez duten egitura zelularrak degradatzen dira. Degradazio prozesu horren ondorioz, egitura zelular berriak sortzeko materialak (aminoazidoak) eta energia lortzen dira. Prozesu hau de Duvé-k eta bestek deskribatu zuten lehenengoz orain dela lau hamarkada, ikusi zutenean arratoi gibelei glukagoi hormonarekin perfusioa egitean mitokondrioak eta zelula barneko egiturak degradatzen zirela [1]. Izan ere, autofagiaren helburu nagusiak dira zelula estres edo energia eskuragarritasun mugatuko egoeretan dagoenean kaltetutako egitura zelularrak degradatzea eta energia oreka mantentzea [2]. Autofagia zelulan berez gertatzen den prozesu bat den arren (autofagia basala), zenbait estres egoeraren aurrean (gosea edo estres oxidatiboa, adibidez) autofagia maila handitu egiten da (autofagia adaptatiboa).

Autofagiari buruz hitz egitean, apoptositik bereiztea komeni da. Izan ere, autofagian zitoplasmako organulu eta egiturak degradatzen dira, eta apoptosian, aldiz, zelula osoa da degradatzen dena. Gainera, azpimarratu behar da, zelula berean bi prozesuak gerta daitezkeela, autofagia izanik lehendabizi gertatzen dena. Oro har, autofagia babes-mekanismotzat hartzen da, zelulek estres maila ez-hilgarrietara egokitzeko ematen duten erantzuna den aldetik. Zenbait kasutan, ordea, autofagiaren ondorioz hil egin daiteke zelula, zelularen osagai garrantzitsuak degradatu direlako edo au- 
tofagiak apoptosiaren aktibazioa bideratu duelako. Zelulak pairatzen duen estresak muga jakin bat gainditzen duenean, edo estres maila bat denboran mantentzen denean, apoptosia izango da aktibatzen dena, zelula deuseztatzeko. Behin apoptosi-prozesua hasten denean, autofagia desaktibatzen da, kaspasek (apoptosiaren bitartekari diren entzimak) autofagian parte hartzen duten zenbait proteina degradatzen dituztelako [3].

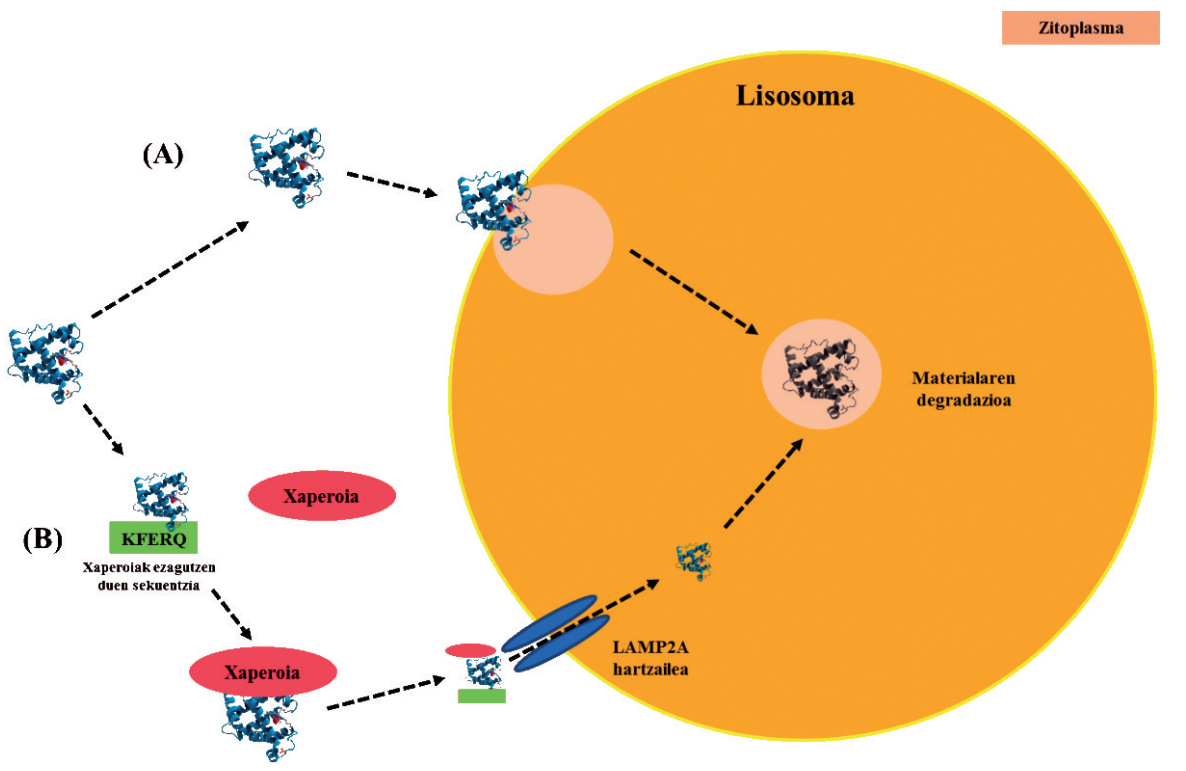

1. irudia. Mikroautofagia prozesua; degradatu beharreko materiala (zitoplasma) lisosoman sortutako inbaginazioen bidez iristen da lisosoma barrura (A). Xaperoi bidezko autofagia; degradatu beharreko materiala xaperoi-konplexu batek identifikatzen du (KFERQ bidez), eta lisosomaren mintzeko hartzaileek (LAMP2A) lisosoma barrura bideratzen dute (B).

Egundaino, hiru autofagia mota deskribatu dira: xaperoi bidezko autofagia, mikroautofagia eta makroautofagia. Hiru motek duten ezaugarri komuna da lisosoma bidez zitosoleko materialaren degradazioa gertatzen dela.

Xaperoi bidezko autofagian, degradatu beharreko materiala (proteinak) zuzenean pasatzen da zitosoletik lisosoma barrura, horren mintza zeharkaturik. Autofagia mota horren ezaugarri nagusia da degradatu beharreko proteinak xaperoi-konplexu batek ezagutzen dituela. Horretarako, xaperoikonplexuak degradatu behar den proteinak aminoazido-sekuentzian duen seinale zehatz bat identifikatzen du (KFERQ bidez) (1. irudia), eta, ondoren, lisosomaren mintzeko hartzaileen bidez (LAMP2A) lisosoma ba- 
rrura bideratzen dira degradazio prozesua osatzeko. Horri esker, posible da kaltetutako proteinak deuseztatzea ondo daudenak bere horretan mantenduz [4]. Mikroautofagiaren kasuan, zitoplasma, lisosomaren inbaginazio batek biltzen du, eta edukia beraren barruan harrapatuta geratzen da. Behin barruan dagoela, edukia (proteinak eta organuluak eskuarki) degradatu egiten da (1. irudia). Uste da autofagia mota ez-selektibo hau zelulako egituren berriztatze basalarekin erlazionatuta dagoela eta beste autofagia motekin koordinatzen dela [5]. Makroautofagiari (autofagia hemendik aurrera) dagokionez, bera da gehien ikertu den eta hobekien ulertzen den autofagia mota (gizakiengan gertatzen diren zenbait gaixotasunetan duen garrantzia dela eta). Beraren ezaugarri nagusia da zitosolaren zati bat autofagosoma izeneko mintz bikoitzeko besikula batek biltzen duela. Jarraian, autofagosoma lisosoma batekin elkartzen da (autolisosoma sortzen du) [6], eta edukiaren degradazioa gertatzen da. Degradazio horren ondorioz, zelulak berak substratu gisa erabiliko dituen konposatuak sortuko dira [7]. Puntu honetatik aurrera, azken autofagia mota horri buruz idatziko da.

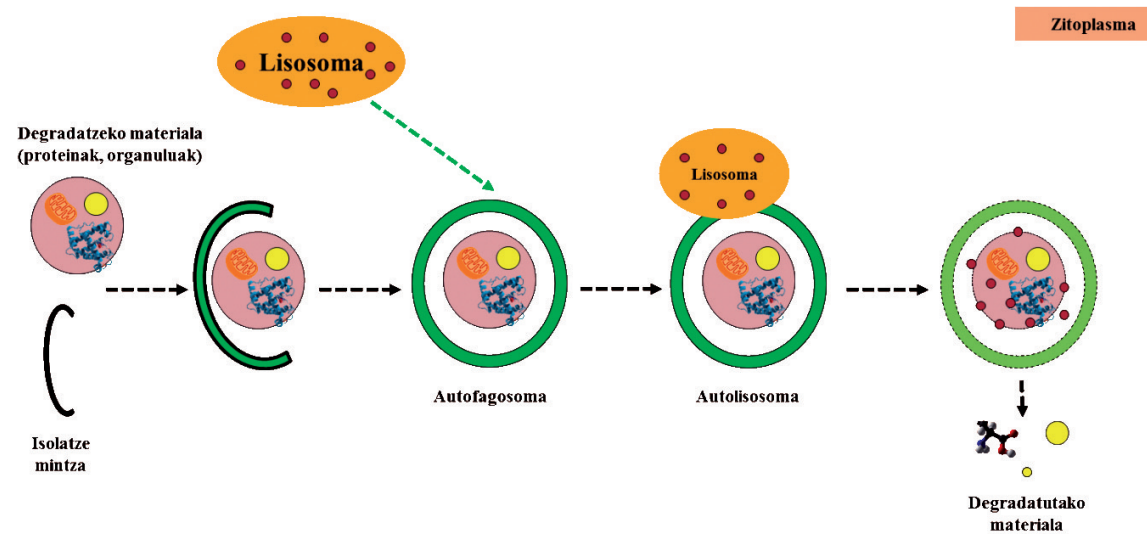

2. irudia. Makroautofagia prozesua: isolatze mintzaren heltzea, autofagosomaren eraketa, autolisosomaren sorrera eta degradazio prozesua.

\section{AUTOFAGIAREN MEKANISMO MOLEKULARRA}

Oro har, autofagian, lau etapa nagusi bereizten dira: hasiera edo indukzioa; nukleazioa; luzapena, eta lisosomarekiko fusioa eta ondoriozko degradazioa.

Nutrizio estresik gabeko egoera normaletan, ugaztunetako rapamizina-itu 1 konplexuak (mTORC1) autofagia inhibitzen du. Horretarako, mTORC1-ak ULK konplexua (ULK1, Atg13, FIP200 eta Atg101) bahitzen $\mathrm{du}$, eta, hala, hura inhibitu eta autofagiaren hasiera saihesten du (3. irudia, 
A atala). Estres egoeretan, ordea (nutriente gabezian, hipoxian edota energia maila baxuetan), mTORC1-en eta ULK1 proteinaren arteko elkarrekintza eteten da, eta, horrenbestez, autofagiaren aktibazioa ahalbidetzen da. Izan ere, nutrienteen eskuragarritasuna mugatua dagoen egoeretan, AMP proteina kinasa (AMPK) aktibatzen da, zeinak mTOR inhibitzen duen (3. irudia, B atala) [8]. Nukleazio fasean, legamiako Atg6-aren ugaztunetako ortologoa den proteinak (Beclin1) eta fosfoinositol 3 kinasak (PI3K) konplexu bat osatzen dute. Konplexu horrek berebiziko garrantzia du, bai besikularen nukleazioan, baita aurreragoko autofagosomaren eta lisosomaren arteko elkarketan ere [9].

(A)

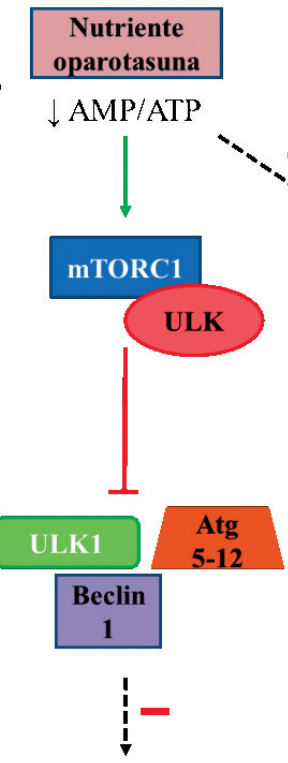

Autofagia
(B)

Aktibazioa

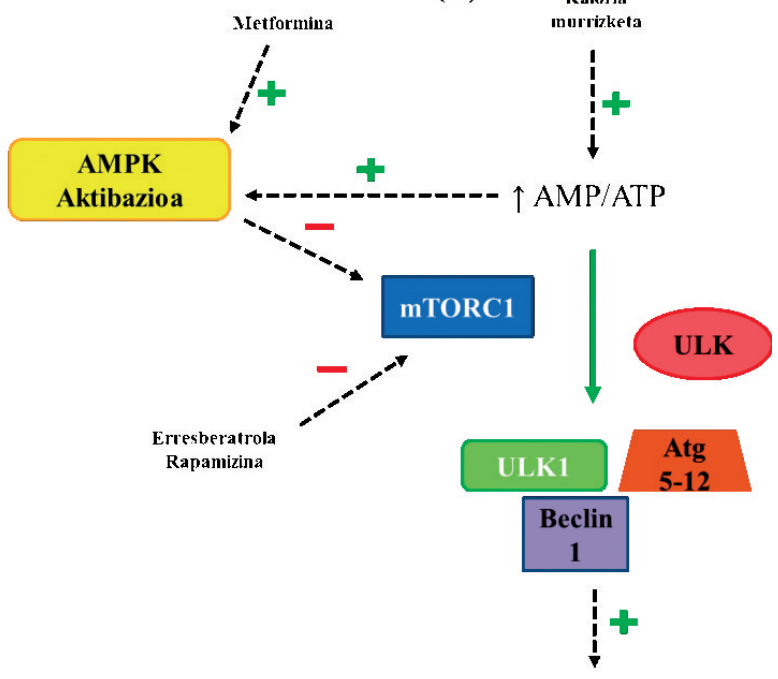

Autofagia

3. irudia. Autofagiaren erregulazioa nutriente oparotasuna dagoen egoeretan (egoera basalean) (A), eta autofagiaren aktibatzaileek horren erregulazioan duten eragina (B).

Nukleazio fasearen ondoren, 5 eta 12 autofagia proteinek osatutako konplexuak (Atg5-Atg12) luzapen fasea erregulatzen du. Fase horretan, autofagosomaren guztizko osaketa burutuko da. Puntu honetan, azpimarratzekoa da mikrotubuluei lotutako proteinaren 3. kate arinaren egoera aldaketa, 1 egoeratik (LC3 I) 2 egoerara (LC3 II) igaroko baita. Izan ere, LC3 II-a autofagosomaren mintzarekin lotzen da, eta, hala, horren elongazioa eta itxiera bideratzen ditu. Ondorioz, autofagia mailaren erakusle gisa 
erabili izan da (LC3 II proteina mailak neurtuz). Hala ere, kontuan izan behar da autofagosoma lisosomarekin elkartzean LC3 II-a degradatzen dela, eta, horrenbestez, LC3 II-aren maila altu bat autofagosomaren eta lisosomaren arteko fusioan gerta daitezkeen arazoen erakusle izan daiteke. Hori dela eta, oro har, LC3 II maila altuak autofagosoma eraketaren handipenarekin erlazionatzen dira, eta ez autofagia prozesuaren aktibazioaren igoerekin [2].

Azkenik, autofagosoma lisosomarekin elkartuko da, eta azken horrek dituen entzimak autofagosomaren edukiarekin kontaktuan jarri eta hura degradatuko dute. Behin degradazioa bukatuz gero, edukia (aminoazidoak eskuarki) zitoplasmara askatuko da. Zelulak proteina berriak sintetizatzeko edo energia lortzeko erregai gisa erabiliko du degradatutako eduki hori [10].

\section{AUTOFAGIAREN INPLIKAZIOA BIZITZAKO HAINBAT EGOERATAN}

Lehen aipatu den bezala, autofagia mekanismo bat da, zeinak zelulari estres egoeretara egokitzea ahalbidetzen dion. Zelulak degradazioaren ondorioz lortzen dituen aminoazidoak estres egoera horretara egokitu ahal izateko beharrezko dituen proteinak sintetizatzeko erabiltzen ditu. Bestetik, aminoazido horiek berak, gantz azidoekin batera, erregai gisa erabil daitezke Krebs-en zikloan, ATPa lortu eta energia maila egokia mantentzeko. Hala ere, zelulen biziraupena bermatzea helburu duen mekanismo honen asaldurak ohikoak dira zenbait egoeratan [11].

\subsection{Neuroendekapenezko gaixotasunak}

Hasiera batean, entzefalopatia espongiformeak, Parkinsona, Alzheimerra edo antzeko gaixotasunak zituzten pazienteen garunetan autofagosoma pilaketa bat gertatzen zela ikusi zen. Hori dela eta, autofagiak gaixotasun horien garapenean eragina zuelako ustea sortu zen.

Hala ere, zenbait ikerketak azaldutakoaren arabera, autofagosoma pilaketa horrek autofagia babes mekanismo gisa aktibatzen dela erakusten du. Horren adibide da neuronetan Atg5 proteina murriztua zuten saguekin egindako ikerketa bat [12]. Ikertzaileek ikusi zuten sagu horien neuronetan proteinen agregatuak pilatzen zirela eta neuroendekapena eragiten zutela (funtzio motorren galera jarraitua). Ikerketa horretan lortutako emaitzek erakutsi zuten beharrezkoa dela neuronetan autofagia maila basal bat mantentzea, haiek behar bezala funtzionatzeko (proteina agregatuak metatzea ekiditen baitu).

Alzheimerraren kasuan, autofagosoma pilaketa halakoen heltze prozesuan gertatzen den asaldura baten ondorio gisa gertatzen dela ikusi da [13]. 
Autofagia eta haren erregulazioa osasunean eta gaixotasunean

Gainera, proposatu da autofagiak paper garrantzitsu bat jokatzen duela gaixotasun horietan sortzen diren proteina agregatuen deuseztapenean. Honen arira, zenbait lanek erakutsi dute ezen autofagia farmako bidez aktibatzen denean, proteina agregatu horien ezabapena handitzeaz batera [14], autofagiaren inhibizioak agregatu horien pilaketa errazten duela [15]. Gaur egun gauza jakina da gaixotasun hauek eragiten dituzten proteinak kaltegarriagoak direla egoera oligomerikoan daudenean. Autofagiak, egoera honetan dauden proteinekiko duen afinitate handiagoa dela eta, babesten du gaixotasun hauetatik [13].

Gaixotasunak aurrera egin ahala, ordea, autofagiak proteina agregatuak ezabatzeko duen gaitasuna asez joaten da. Gerta daiteke, gainera, agregatuek autofagiarako ezinbestekoak diren proteinak bahitzea eta, hala, autofagosomen heltze egokia oztopatzea. Garun mailan adinarekin gertatzen den Beclin1-aren eta autofagian parte hartzen duten beste zenbait proteinaren espresio murrizketa gehitu behar zaio horri [16].

\subsection{Obesitatea}

Obesitatea egoera patologiko bat da, zeinean bai gorputzak bai zelulek gehiegizko nutriente fluxu jarraitu bat jasaten duten. Egoera horretan, oreka metaboliko bat mantentzeko ezintasunaren ondorioz, estres egoera bat sortzen da, zeinak hantura eta organuluen funtzio galera eragiten dituen. Horren adibide da erretikulu endoplasmatikoko estresa; erretikulu endoplasmatikoak besikula autofagikoak sintetizatzeko beharrezkoak diren mintzak sortzen ditu. Ikusi da obesitate egoeretan autofagia murriztuta dagoela eta, horren ondorioz, erretikulu endoplasmatikoaren estresa handituta [17].

Hala ere, kontuan izan behar da, autofagia berez prozesu konplexua izateaz gain, beraren efektuak ere konplexuak izan daitezkeela. Horren adibidea da obesitatean gantz ehun zurian gertatzen dena. Ehun horretan, beste egoera patologikoetan ez bezala, autofagiaren handipen bat obesitatearen garapenarekin erlazionatuta dagoela uste da [18]. Horren adibide dira gantz ehun zurian 7 eta 8 autofagia proteinetan (Atg7 eta Atg8) knockout (KO) diren saguak erabiliz egin diren aurkikuntzak. Izan ere, animalia horien gantz ehun zuriak gantz ehun arrearen itxura hartzen du, zeinak metabolismo handiagoa duen (mitokondrio eduki handia) eta obesitatearekiko erresistente egiten dituen $[19,20]$.

\subsection{Diabetesa}

Diabetesaren (batik bat 2 motakoa) eta autofagiaren arteko erlazioa aspalditik ikertua izan da. Zenbait ikerketak proposatu dute autofagiaren igoera batek areko $\beta$ zelulen estres oxidatiboaren maila murrizten lagundu dezakeela. Horren harira, Atg7 proteina gutxitua duen sagu modelo batean 
intsulinarekiko erresistentziaren garapena eta areko $\beta$ zelula kopuruaren murrizketa deskribatu dira [21]. Gehiegizko kaloria ingestioa dagoen egoeretan, eta hori gantzetan aberatsa den dieta baten bidez gertatzen denean, areko $\beta$ zeluletan autofagiaren igoera bat gertatzen dela ikusi da. Igoera hori dieta mota horrek sortzen duen intsulinarekiko erresistentziari erantzuteko mekanismo gisa agertzen da. Egoera hauetan ohikoa den gantz azido askeen maila altua proposatu da erantzun horren bitartekari gisa. Izan ere, gantz azido askeen maila altua den kasuetan, autofagiaren igoerak kaltetutako mitokondrio eta egitura zelularren gehiegizko pilaketatik babestuko lituzke $\beta$ zelulak [22].

Gizakietan egindako ikerketa batean, 2 motako diabetesa zuten gaixoen $\beta$ zeluletako autofagia-markatzaileak aztertu ziren. Emaitzek erakutsi zuten diabetesa dagoenean autofagia-material pilaketa bat gertatzen zela, eta pilaketa hori, bestalde, material horren deuseztapenaren asaldura bati egotzi zitzaion [23]. Egileek ikusi zuten metforminarekin tratatzean, zeinak AMPK aktibatzen duen, autofagia-besikulen pilaketa murriztu zela. Ondorioz, proposatu zuten metforminak eragindako AMPKren aktibazioak autofagia errazten zuela (mTOR inhibituz) bai eta autofagia-materialaren deuseztapena ere.

\subsection{Gibel gantzatsu ez-alkoholikoa}

Gaur egun, gibel gantzatsu ez-alkoholikoa gibeleko gaixotasunik arruntena da mendebaldeko gizartean. Gaixotasun hau gibelari erasaten dion sindrome metabolikoaren adierazpen gisa ezagutzen da. Gibelean gehiegizko gantz metaketa bat gertatzen denean eta metaketa hori denboran luzatzen denean, esteato-hepatitisa garatu daiteke, zeina zirrosi edo gibeleko minbizi bihur daitekeen [24].

Lipofagia autofagia mota bat da, zeina tamaina handiko gantz tantak tamaina txikiagotan zatikatzeagatik nabarmentzen den. Apurketa horren ondorioz sortzen diren tamaina txikiko molekulak errazago degradatu edo erabili ohi dira [25]. Lipofagiak gibelean defentsa mekanismoaren papera betetzen du, gehiegizko gantz metaketa ekidinez. Uste da autofagiaren asaldurak esteatosi ez-alkoholikotik abiatuta agertzen den esteato-hepatitisaren eta zirrosiaren garapenarekin erlazionatuta daudela. Horren erakusle izango litzateke Atg7 proteina inhibitua zuen sagu modelo batekin egindako ikerketa. Ikertzaileek ikusi zuten sagu horiek, autofagia murriztua edukitzeaz gainera, gantz kantitate handiagoa pilatzen zutela gibelean [25]. Beste ikerketa batean ikusi zen hidrogeno sulfidoak (autofagiaren aktibatzaile indartsu bat) gizaki eta saguetan odoleko triglizerido mailak jaisten zituela eta gibeleko gantz edukia murrizten zuela eta, hala, autofagia aktibatzen zela. Saguen kasuan ikusi da autofagiaren aktibazioa AMPK-mTOR ardatzean eraginez bideratzen duela [26]. 
Autofagia eta haren erregulazioa osasunean eta gaixotasunean

\subsection{Zahartzea}

Denbora luzez pentsatu izan da zahartze prozesuan zehar autofagiaren funtzionaltasuna murrizten dela. Hainbat ikerlanek erakutsi dute adinarekin ehunetan autofagiarako ezinbestekoak diren zenbait proteinaren espresioa murrizten dela [27]. Horietako batean deskribatu da adinak arratoien gibeleko hormonen erregulazioan (intsulina eta glukagoia) eta autofagosomen degradazioan aldaketak eragiten dituela [28]. Ondorioz, lisosoma barruan geratzen den erdi digeritutako materialaren pilaketak eragin negatiboak izango lituzke lisosomek autofagosomekin elkartzeko duten ahalmenean.

Autofagiak kaltetutako osagai zelularrak deuseztatzen betetzen duen funtzioak mitokondrioen metabolismo egoki bat mantentzea ahalbidetzen du, oxigenoaren espezie erreaktiboen (ROS) ekoizpena murriztuz. Esperimentazio modelo ezberdinetan ( $C$ elegans eta karraskarietan) ikusi da mitokondrioen metabolismoa eta ROSen ekoizpena murrizten dituzten aldaketa genetikoek luzarazten dutela modeloen biziraupena [29]. Bestetik, kaloria murrizketak (KM), zeina autofagiaren aktibatzaile fisiologiko nagusia den, espezie guztien biziraupena luzatzen du (primateena barne), eta, hala, autofagiaren eta biziraupenaren artean dagoen erlazioa agerian uzten. Erlazio hori KMk biziraupenean duen eragina autofagia inhibitzean indargabetuta geratzen dela erakutsi duten ikerketetan berretsi da [27].

\section{AUTOFAGIAREN AKTIBATZAILEAK}

Lehen aipatu den bezala, autofagia (edo haren asaldura) zenbait gaixotasunen sorrera eta garapenarekin erlazionatzen da. Hori dela eta, komunitate zientifikoa aspalditik dabil prozesu hau aktibatu edo egoera normalera itzultzen duten molekula edo esku-hartzeen bila.

\subsection{Kaloria murrizketa}

Esku-hartze dietetiko hau egunean hartzen den kaloria kopurua \% 20-40 murriztean oinarritzen da, desnutriziorik gabe (dietako nutriente banaketa egokia mantenduz) [30]. Aurreko puntuetan adierazi den bezala, KM gaurdaino ezagutzen den autofagiaren aktibatzaile fisiologiko indartsuena da [31]. KMk mTORC1 eta ULK proteinek eratzen duten konplexuaren banaketa eraginez bideratzen du autofagia. Nutrienteen eskuragarritasuna mugatua den kasuetan, AMP/ATP erlazioa handitzen da, eta, ondorioz, AMPK aktibatzen. AMPK-k, berriz, ULK1 proteina zuzenean fosforilatzen du, autofagia aktibatuz (3. irudia). Bestetik, AMPK aktibatuta dagoenean, mTOR-i lotutako proteina erregulatzailea (Raptor) fosforilatzen du, eta, hala, mTORC1-en jarduera modu alosterikoan inhibitzen [8]. 


\subsection{Erresberatrola}

Erresberatrola (3, 5, 4'-trihidroxi-trans-estilbenoa) estilbenoen familiako konposatu fenolikoa da, landareek patogenoen erasoetatik eta erradiazio ultramoretik babesteko ekoizten dutena [32]. Konposatu hori, zeina bere efektu onuragarriengatik luze eta zabal ikertua izan den, KMren imitatzaile gisa ere ezagun da [33].

In vitro eta in vivo modeloekin eginiko ikerketek erakutsi dute erresberatrolak Alzheimerrean eta Parkinsonean eta antzeko gaixotasunetan dituen efektu onuragarriak autofagiaren aktibazioaren bidez gertatzen direla [34, 35]. Bestetik, ikusi da erresberatrolak glukosa maila altuek arratoi diabetikoetan eragindako neurotoxikotasunaren aurka ematen duen babesa autofagiaren aktibazioak bideratzen duela [36]. Izan ere, modelo zelularretan egindako saioek erakutsi dutenez, erresberatrolak mTOR zuzenean inhibituz aktibatzen du autofagia (3. irudia). Horretarako, erresberatrola mTOR-k ATP molekulak lotzeko duen tokian jartzen da [37]. Gainera, erresberatrolak AMPK ere aktibatzen duenez, proteina kinasa honen bidez autofagia zeharkako modu batean ere aktibatuko luke.

\subsection{Metformina}

Biguaniden taldeko konposatu hau 2 motako diabetesa tratatzeko farmakorik erabiliena da. Gainera, minbiziaren tratamendurako ere eraginkorra dela ikusi da. Uste da metforminak minbiziaren aurka dituen efektuetako batzuk autofagia aktibatzeko duen gaitasunari zor dizkiola [38].

Ikusi denez, metforminak, saguetan, melanoma tumoreen hazkundea inhibitzen du, eta aldi berean autofagiaren eta apoptosiaren markatzaile kopurua handitzen. Bestetik, Beclin 1-en inhibizioak edo autofagiaren blokeatzaileek metforminak bideratutako efektu zitotoxikoa indargabetzen dutela deskribatu da [39]. Konposatu horrek eragiten duen autofagiaren aktibazioa AMPKren bidez gertatzen dela proposatu da (3. irudia).

\subsection{Rapamizina eta analogoak}

Rapamizina (edo sirolimusa) Streptomyces hygroscopicus bakterioak ekoitzitako konposatu bat da, mTOR-en inhibitzaile naturala. Konposatu hau zein haren analogoak (everolimusa, temsirolimusa eta deforolimusa, rapalogo izenez ezagunak) autofagia aktibatzeko gai dira mTORC1 inhibituz (3. irudia) [40].

Konposatu hauek oso erabiliak dira minbizien tratamenduan, eta uste da haien efektu onuragarrietako asko autofagia aktibatuz lortzen direla. Hala ere, mTOR-k autofagia ez den beste mekanismo molekular batzuk ere erregulatzen dituenez (proteina eta lipidoen sintesia, metabolismoa edo proliferazio zelularra), ezin daiteke esan minbizian dituen eragin positi- 
Autofagia eta haren erregulazioa osasunean eta gaixotasunean

boak autofagiaren aktibazioagatik bakarrik gertatzen direnik. Horregatik, nahiz eta autofagiaren aktibatzaile indartsuak direla ikusi den (mTOR-ren inhibizioz) ikerketa gehiago beharrezkoak dira konposatu horiek autofagia helburu terapeutikoarekin aktibatzeko erabili baino lehen [40].

\section{AUTOFAGIAREN BALIZKO ERABILERA TERAPEUTIKOAK}

Autofagia orain urte gutxi berraurkitu zenetik egindako lanek mekanismo horri buruzko ezagutza sakontzen eta prozesuak zeluletan betetzen dituen funtzioak argitzen lagundu dute. Gaur egun, komunitate zientifikoaren helburuetako bat autofagia gaixotasunen tratamendurako estrategia terapeutiko gisa erabili ahal izatea da.

Ikerketek erakutsi dute autofagiaren aktibatzaileak minbizien tratamendurako erabil daitezkeela, bai autofagiak bideratutako heriotza zelularra eraginez, baita botika kimioterapikoen eraginkortasuna handituz ere [41]. Neuroendekapenezko gaixotasunei dagokionez, Rapamizinaren analogoak gizakietan erabiltzeko hautagai gisa proposatu dira, modelo esperimentaletan lortutako emaitzak oinarritzat hartuta [11]. Diabetesak eragindako nefropatiaren kasuan, horren patogenesiak autofagiaren asaldurarekin zerikusia duenez, mekanismo honen aktibatzaileak erreminta terapeutiko moduan erabiltzea proposatu da [42].

Nahiz eta autofagiaren aktibazioak osasunean onurak sor ditzakeela ikusi den, gaur egun oraindik ez dira ezagutzen prozesu honen aktibazioak eragindako efektu guztiak. Izan ere, zenbait egoeratan autofagiaren aktibazioa kaltegarria izan daitekeela proposatu da. Minbizi zelulen kasuan, esaterako, autofagiak zelula horiei programatutako heriotza zelularra saihesten lagunduko lieke, dituzten energia beharrizan handiagotuak asebetez [40]. Adibide horrek argi erakusten du autofagiaren inaktibazioa nola eragin ikertzea ere garrantzitsua dela. Kontuan izan behar da autofagia oso prozesu konplexua dela, eta, nahiz eta azken hamarkadetan egindako ikerketek hura hobeto ulertzen lagundu duten, oraindik ere ezagutza zabalagoa beharrezkoa da autofagiaren erregulazio positibo eta negatiboari buruz. Datozen urteetan egingo diren ikerketek (zelula eta animalietan nagusiki) erakutsiko dute etorkizunean autofagia gizakiaren zenbait gaixotasun eta egoera sendatzen edo hobetzen lagungarria izan daitekeen.

\section{BIBLIOGRAFIA}

[1] GLICK D., BARTH S., MACLEOD K.F. 2010. «Autophagy: Cellular and molecular mechanisms». The Journal of Pthology, 221, 3-12.

[2] CZAJA, M.J. 2011. «Functions of autophagy in hepatic and pancreatic physiology and disease». Gastroenterology, 140, 1895-1908. 
[3] MARIÑO G., NISO-SANTANO M., BAEHRECKE E.H., KROEMER G. 2014. «Self-consumption: The interplay of autophagy and apoptosis». Nature Reviews Molecular Cell Biology, 15, 81-94.

[4] CUERVO A.M., WONG E. 2014. "Chaperone-mediated autophagy: Roles in disease and aging». Cell Research, 24, 92-104.

[5] LI W.W., LI J., BAO J.K. 2012. «Microautophagy: Lesser-known self-eating». Cellular and Molecular Life Sciences, 69, 1125-1136.

[6] KLIONSKY D.J., ESKELINEN E.J., DERETIC V. 2014. «Autophagosomes, phagosomes, autolysosomes, phagolysosomes, autophagolysosomes... Wait, I'm confused». Autophagy, 10, 549-551.

[7] ABOUNIT K., SCARABELLI T.M., MCCAULEY R.B. 2012. «Autophagy in mammalian cells». World Journal of Biological Chemistry, 3, 1-6.

[8] KIM J., KUNDU M., VIOLLET B., GUAN K.L. 2011. «Ampk and mtor regulate autophagy through direct phosphorylation of ulk1». Nature Cell Biology, 13, 132-141.

[9] YANG J.S., LU C.C., KUO S.C., HSU Y.M., TSAI S.C., CHEN S.Y., CHEN Y.T., LIN Y.J., HUANG Y.C., CHEN C.J., et al. 2017. «Autophagy and its link to type ii diabetes mellitus». Biomedicine, 7, 8 .

[10] WONG A.S., CHEUNG Z.H., IP N.Y. 2011. «Molecular machinery of macroautophagy and its deregulation in diseases». Biochimica et Biophysica Acta, 1812, 1490-1497.

[11] LEVINE B., KROEMER G. 2008. «Autophagy in the pathogenesis of disease». Cell, 132, 27-42.

[12] HARA T., NAKAMURA N., MATSUI M., YAMAMOTO A., NAKAHARA Y., SUZUKI-MIGISHIMA R., YOKOYAMA M., MISHIMA K., SAITO I., OKANO H., MIZUSHIMA N. 2006. «Supression of basal autophagy in neural cells causes neurodegenerative disease in mice». Nature, 441, 885-889.

[13] MARTINEZ-VICENTE M., CUERVO A.M. 2007. «Autophagy and neurodegeneration: When the cleaning crew goes on strike». The Lancet Neurology, 6, 352-361.

[14] RUBINSZTEIN D.C. 2007. «Autophagy induction rescues toxicity mediated by proteasome inhibition». Neuron, $\mathbf{5 4}, 854-856$.

[15] JIA K., HART A.C., LEVINE B. 2007. «Autophagy genes protect against disease caused by polyglutamine expansion proteins in caenorhabditis elegans». Autophagy, 3, 21-25.

[16] SHIBATA M., LU T., FURUYA T., DEGTEREV A., MIZUSHIMA N., YOSHIMORI T., MACDONALD M., YANKNER B., YUAN J. 2006. «Regulation of intracellular accumulation of mutant huntingtin by beclin 1». The Journal of Biological Chemistry, 281, 14474-14485.

[17] YANG L., LI P., FU S., CALAY E.S., HOTAMISLIGIL G.S. 2010. «Defective hepatic autophagy in obesity promotes er stress and causes insulin resistance». Cell Metabolism, 11, 467-478.

[18] KOVSAN J., BLÜHER M., TARNOVSCKI T., KLÖTING N., KIRSHTEIN B., MADAR L., SHAI I., GOLAN R., HARMAN-BOEHM I., SCHÖN 
Autofagia eta haren erregulazioa osasunean eta gaixotasunean

M.R., et al. 2011. «Altered autophagy in human adipose tissues in obesity». The Journal of Clinical Endocrinology and Metabolism, 96, E268-277.

[19] ZHANG Y., GOLDMAN S., BAERGA R., ZHAO Y., KOMATSU M., JIN S. 2009. «Adipose-specific deletion of autophagy-related gene 7 (atg7) in mice reveals a role in adipogenesis». Procceedings of the National Academy of Sciences of the United States of America, 106, 19860-19865.

[20] SINGH R., XIANG Y., WANG Y., BAIKATI K., CUERVO A.M., LUU Y.K., TANG Y., PESSIN J.E., SCHWARTZ G.J., CZAJA M.J. 2009. «Autophagy regulates adipose mass and differentiation in mice». The Journal of Clinical Investigation, 119, 3329-3339.

[21] KIM J., CHEON H., JEONG Y.T., QUAN W., KIM K.H., CHO J.M., LIM Y.M., OH S.H., JIN S.M., KIM J.H., et al. 2014. «Amyloidogenic peptide oligomer accumulation in autophagy-deficient $\beta$ cells induces diabetes». The Journal of Clinical Investigation, 124, 3311-3324.

[22] EBATO C., UCHIDA T., ARAKAWA M., KOMATSU M., UENO T., KOMIYA K., AZUMA K., HIROSE T., TANAKA K., KOMINAMI E., et al. 2008. "Autophagy is important in islet homeostasis and compensatory increase of beta cell mass in response to high-fat diet». Cell Metabolism, 8, 325-332.

[23] MASINI M., BUGLIANI M., LUPI R., DEL GUERRA S., BOGGI U., FILIPPONI F., MARSELLI L., MASIELLO P., MARCHETTI P. 2009. «Autophagy in human type 2 diabetes pancreatic beta cells». Diabetologia, 52, 1083-1086.

[24] DONGIOVANNI P., LANTI C., RISO P., VALENTI L. 2016. «Nutritional therapy for nonalcoholic fatty liver disease». The Journal of Nutritional Biochemistry, 29, 1-11.

[25] SINGH R., KAUSHIK S., WANG Y., XIANG Y., NOVAK I., KOMATSU M., TANAKA K., CUERVO A.M., CZAJA M.J. 2009. «Autophagy regulates lipid metabolism». Nature, 458, 1131-1135.

[26] SUN L., ZHANG S., YU C., PAN Z., LIU Y., ZHAO J., WANG X., YUN F., ZHAO H., YAN S., et al. 2015. «Hydrogen sulfide reduces serum triglyceride by activating liver autophagy via the ampk-mtor pathway». American Journal of Physiology, Endocrinology and Metabolism, 309, E925-935.

[27] RUBINSZTEIN D.C., MARIÑO G., KROEMER G. 2011. «Autophagy and aging». Cell, 146, 682-695.

[28] DEL ROSO A., VITTORINI S., CAVALLINI G., DONATI A., GORI Z., MASINI M., POLLERA M., BERGAMINI E. 2003. «Ageing-related changes in the in vivo function of rat liver macroautophagy and proteolysis». Experimental Gerontology, 38, 519-527.

[29] LEVINE B., KLIONSKY D.J. 2004. «Development by self-digestion: Molecular mechanisms and biological functions of autophagy». Developmental Cell, 6, 463-477.

[30] CANTÓ C., AUWERX J. 2009. «Caloric restriction, sirt1 and longevity». Trends in Endocrinology and Metabolism, 20, 325-331. 
[31] NTSAPI C., LOOS B. 2016. «Caloric restriction and the precision-control of autophagy: A strategy for delaying neurodegenerative disease progression». Experimental Gerontology, 83, 97-111.

[32] WALLE T. 2011. «Bioavailability of resveratrol». Annals of the New York Academy of Sciences, 1215, 9-15.

[33] BARGER J.L., KAYO T., VANN J.M., ARIAS E.B., WANG J., HACKER T.A., WANG Y., RAEDERSTORFF D., MORROW J.D., LEEUWENBURGH C., et al. 2008. «A low dose of dietary resveratrol partially mimics caloric restriction and retards aging parameters in mice». PloS one, $\mathbf{3}$, e2264.

[34] VINGTDEUX V., GILIBERTO L., ZHAO H., CHANDAKKAR P., WU Q., SIMON J.E., JANLE E.M., LOBO J., FERRUZZI M.G., DAVIES P., et al. 2010. «Amp-activated protein kinase signaling activation by resveratrol modulates amyloid-beta peptide metabolism». The Journal of Biological Chemistry, 285, 9100-9113.

[35] WU S., AGUILAR A.L., OSTROW V., DE LUCA F. 2011. «Insulin resistance secondary to a high-fat diet stimulates longitudinal bone growth and growth plate chondrogenesis in mice». Endocrinology, 152, 468-475.

[36] HUANG S.S., DING D.F., CHEN S., DONG C.L., YE X.L., YUAN Y.G., FENG Y.M., YOU N., XU J.R., MIAO H., et al. 2017. «Resveratrol protects podocytes against apoptosis via stimulation of autophagy in a mouse model of diabetic nephropathy». Scientific Reports, 7, 45692.

[37] PARK D., JEON H., LEE M.N., KOH A., KWON O., YANG Y.R., NOH J., SUH P.G., PARK H., RYU S.H. 2016. «Resveratrol induces autophagy by directly inhibiting mtor through atp competition». Scientific Reports, $\mathbf{6}$, 21772 .

[38] TOMIC T., BOTTON T., CEREZO M., ROBERT G., LUCIANO F., PUISSANT A., GOUNON P., ALLEGRA M., BERTOLOTTO C., BEREDER J.M., et al. 2011. «Metformin inhibits melanoma development through autophagy and apoptosis mechanisms». Cell Death \& Disease, 2, e199.

[39] TAKAHASHI A., KIMURA F., YAMANAKA A., TAKEBAYASHI A., KITA N., TAKAHASHI K., MURAKAMI T. 2014. «Metformin impairs growth of endometrial cancer cells via cell cycle arrest and concomitant autophagy and apoptosis». Cancer Cell International, 14, 53.

[40] BYUN S., LEE E., LEE K.W. 2017. «Therapeutic implications of autophagy inducers in immunological disorders, infection, and cancer». International Journal of Molecular Sciences, 18.

[41] LAW B.Y., WANG M., MA D.L., AL-MOUSA F., MICHELANGELI F., CHENG S.H., NG M.H., TO K.F., MOK A.Y., KO R.Y., et al. 2010. «Alisol b, a novel inhibitor of the sarcoplasmic/endoplasmic reticulum $\mathrm{ca}^{(2+)}$ atpase pump, induces autophagy, endoplasmic reticulum stress, and apoptosis». Molecular Cancer Therapeutics, 9, 718-730.

[42] KITADA M., OGURA Y., MONNO I., KOYA D. 2017. «Regulating autophagy as a therapeutic target for diabetic nephropathy». Current Diabetes Reports, 17, 53. 